\title{
Analisis Pengaruh Ion Cd(II) Pada Penentuan Ion Fe(II) dengan Pengompleks 1,10- Fenantrolin Menggunakan Spektrofotometer UV-Vis
}

\author{
Ninda Aprilita Rachmasari dan R. Djarot Sugiarso K.S \\ Jurusan Kimia, Fakultas Matematika dan Ilmu Alam, Institut Teknologi Sepuluh Nopember (ITS) \\ Jl. Arief Rahman Hakim, Surabaya 60111 Indonesia \\ e-mail: djarot@chem.its.ac.id
}

\begin{abstract}
Abstrak-Penelitian tentang analisis pengaruh ion $\mathrm{Cd}(\mathrm{II})$ pada penentuan $\mathrm{Fe}^{3+}$ dengan pengompleks 1,10-fenantrolin, telah dilakukan menggunakan spektrofotometer UV-Vis. Kompleks Fe(III) Fenantrolin memiliki panjang gelombang maksimum $320 \mathrm{~nm}$ dengan absorbansi sebesar 0,285 . Kompleks ion pengganggu, Cd(II) Fenantrolin mempunyai panjang gelombang maksimum $316 \mathrm{~nm}$ dengan absorbansi 0,297. Koefisien korelasi (r) diperoleh pada kurva kalibrasi sebesar 0,9991 dengan persamaan $y=0,1016 x-0,0006$. Hasil menunjukkan bahwa Cd (II) mulai mengganggu analisis Besi pada konsentrasi $0,6 \mathrm{ppm}$. Dengan \% recovery $121.574 \%$.
\end{abstract}

Kata Kunci- $\mathrm{Fe}^{3+} ; \quad$ 1,10-Fenantrolin; $\quad \mathrm{Cd}^{2+}$; Spektrofotometer UV-Vis.

\section{PENDAHULUAN}

CENYAWA kompleks merupakan gabungan antara Oion logam dan ligan, dimana ligan akan mendonorkan pasangan elektron bebasnya kepada ion logam. Pada senyawa kompleks, logam pusatnya memiliki bilangan oksida nol dan positif, yang biasanya memiliki orbital kosong seperti logam-logam transisi sehingga dapat menerima pasangan elektron bebas dari ligan. Sedangkan ligannya dapat bermuatan netral atau negatif, yang kemudian memberi atau mendonorkan pasangan elektron bebas kepada logam pusatnya [1].

Logam pusat pada senyawa kompleks seperti besi merupakan suatu logam pada deret transisi pertama yang dapat menerima pasangan elektron bebas dari ligannya. Besi memiliki nomor atom 26 dengan konfigurasi $3 \mathrm{~d}^{6}$ $4 s^{2}$. Besi merupakan unsur keempat terbesar yang ada pada kerak bumi. Dalam bentuk padatan besi berwarna abu-abu. Dalam bentuk cairan, besi dapat teroksidasi dari $\mathrm{Fe}^{2+}$ menjadi $\mathrm{Fe}^{3+}$ [2]. Namun yang paling banyak ditemui adalah $\mathrm{Fe}^{3+}$ karena sifatnya yang lebih stabil.

Ligan dapat mendonorkan pasangan elektron bebas pada besi seperti 1,10-fenantrolin. Ketika ligan tersebut memberikan pasangan elektron bebas pada atom pusat besi, maka dapat membentuk Fe(III) fenantrolin yang stabil. Pada beberapa penelitihan, digunakan $\mathrm{Fe}^{2+}$ karena dapat membentuk kompleks dengan fenantrolin yang stabil pada rentang waktu dua jam, tetapi harus direduksi dahulu menggunakan agen pereduksi dari $\mathrm{Fe}^{3+}$. Sedangkan $\mathrm{Fe}^{3+}$ stabil hanya pada rentang waktu 20 menit. Namun pada penelitian kali ini tidak perlu menggunakan agen pereduksi, karena besi yang digunakan adalah $\mathrm{Fe}^{3+}$.
Kompleks Fe(III) fenantrolin dapat diukur absorbansinya menggunakan spektrofotometer UV-Vis pada panjang gelombang $300-380 \mathrm{~nm}$ dengan warna pengompleks merah gelap. Berdasarkan penelitihan terdahulu oleh [3], $\mathrm{Fe}(\mathrm{III})$ fenantrolin memiliki panjang gelombang maksimum $360 \mathrm{~nm}$ dengan $\mathrm{pH}$ optimum 3,5 dan stabil hanya pada waktu 20 menit. Karena setelah 20 menit akan mengalami perubahan sifat menjadi tidak stabil lagi.

Analisis $\mathrm{Fe}^{3+}$ dengan pengompleks fenantrolin ini dapat diganggu oleh beberapa ion logam yang lainnya seperti $\mathrm{Co}^{2+}$ (Nina Anjarsari, 2015) dan $\mathrm{Ag}^{+}$(Sisca Dianawati, 2013). Namun pada penelitian kali ini akan digunakan ion logam $\mathrm{Cd}^{2+}$. Dan akan diamati kondisi optimum Besi(III) fenantrolin ketika diberi pengganggu ion logam $\mathrm{Cd}^{2+}$

Ion $\mathrm{Cd}^{2+}$ atau Kadmium merupakan kristal putih-perak yang memiliki nomer atom 48. Kadmium merupakan salah satu jenis logam berat yang berbahaya karena elemen ini beresiko tinggi terhadap pembuluh darah [4].

Keberadaan Kadmium sebagai ion logam pengganggu yang diberikan kepada $\mathrm{Fe}$ (III) fenantrolin, dimungkinkan dapat mengganggu kestabilan pada kompleks Fe(III) fenantrolin [5].

Berdasarkan penelitian sebelumnya, kadmium dapat mengganggu kestabilan besi pada baterai. Kandungan kadmium di dalam komposisi baterai mengganggu kestabilan besi yang ada pada baterai, sehingga menyebabkan besi lebih mudah berkarat [6].

\section{URAIAN PENELITIAN}

\section{A. Pembuatan Larutan Stok Fe(III) 100 ppm}

Serbuk $\mathrm{FeCl}_{3} \cdot 6 \mathrm{H}_{2} \mathrm{O}$ ditimbang sebanyak 0,0484 gram ke dalam gelas beker $100 \mathrm{~mL}$, lalu ditambahkan aqua DM secukupnya, dan dipindahkan ke dalam labu ukur $100 \mathrm{~mL}$. Larutan tersebut diencerkan sampai tanda batas sambil dikocok agar homogen.

\section{B. Pembuatan Larutan Stok Cd(II) 100 ppm}

Serbuk $\mathrm{CdCl}_{2}$ ditimbang sebanyak 0,0163 gram ke dalam botol timbang, lalu ditambahkan aqua DM secukupnya, dan diaduk hingga larut kemudian dipindahkan ke dalam labu ukur $100 \mathrm{~mL}$. Larutan tersebut diencerkan sampai tanda batas sambil dikocok agar homogen. 


\section{Pembuatan Larutan Buffer 1,10-Fenantrolin 1000 ppm}

Larutan 1,10-fenantrolin $1000 \mathrm{ppm}$, dibuat dengan cara ditimbang 0,1000 gram serbuk 1,10-fenantrolin, kemudian dilarutkan dengan aqua DM panas secukupnya, ditunggu larutan hingga suhunya sama dengan suhu ruang, lalu diencerkan hingga volume 100 $\mathrm{mL}$ dan dikocok sampai homogen.

\section{Pembuatan Larutan Buffer Asetat pH 3,5}

Natrium asetat trihidrat $\left(\mathrm{CH}_{3} \mathrm{COONa} .3 \mathrm{H}_{2} \mathrm{O}\right)$ ditimbang sebanyak 0,3972 gram, lalu ditambah dengan asam asetat $\left(\mathrm{CH}_{3} \mathrm{COOH}\right)$ sebanyak $5 \mathrm{~mL}$, kemudian diencerkan dengan aqua $\mathrm{DM}$ dalam labu ukur volume $50 \mathrm{~mL}$, dan dikocok sampai homogen.

\section{E. Penentuan Panjang Gelombang Maksimum Fe(III) fenantrolin}

Penentuan panjang gelombang maksimum $\mathrm{Fe}(\mathrm{III})$ fenantrolin ditentukan dengan cara, diambil $0,5 \mathrm{~mL}$ larutan Fe(III) 100 ppm, lalu dimasukkan dalam labu ukur $10 \mathrm{~mL}$, kemudian ditambahkan dengan $1,5 \mathrm{~mL}$ larutan 1,10-fenantrolin $1000 \mathrm{ppm} ; 1 \mathrm{~mL}$ buffer asetat $\mathrm{pH} \quad 3,5$ dan $5 \mathrm{~mL}$ aseton. Campuran tersebut ditambahkan aqua DM hingga volume $10 \mathrm{~mL}$, dikocok hingga homogen dan didiamkan selama 5 menit. Selanjutnya diukur absorbansinya pada panjang gelombang 300 - $750 \mathrm{~nm}$ dengan rentang $1 \mathrm{~nm}$. Tiap prosedur, diulang sebanyak 3 kali. Panjang gelombang maksimum, ditentukan dengan absorbansi maksimum yang telah diperoleh.

\section{F. Penentuan Panjang Gelombang Maksimum Cd(II) fenantrolin}

Penentuan panjang gelombang maksimum $\mathrm{Cd}(\mathrm{II})$ fenantrolin ditentukan dengan cara, diambil $0,5 \mathrm{~mL}$ larutan $\mathrm{Cd}(\mathrm{II}) 100 \mathrm{ppm}$, lalu dimasukkan dalam labu ukur $10 \mathrm{~mL}$, kemudian ditambahkan dengan $1,5 \mathrm{~mL}$ larutan 1,10-fenantrolin $1000 \mathrm{ppm} ; 1 \mathrm{~mL}$ buffer asetat $\mathrm{pH} \quad 3,5$ dan $5 \mathrm{~mL}$ aseton. Campuran tersebut ditambahkan aqua DM hingga volume $10 \mathrm{~mL}$, dikocok hingga homogen dan didiamkan selama 5 menit. Selanjutnya diukur absorbansinya pada panjang gelombang $300-750 \mathrm{~nm}$ dengan rentang $1 \mathrm{~nm}$. Tiap prosedur, diulang sebanyak 3 kali. Panjang gelombang maksimum, ditentukan dengan absorbansi maksimum yang telah diperoleh.

\section{G. Pembuatan Kurva Kalibrasi Besi(III) Fenantrolin}

Larutan Fe(III) 100 ppm dimasukkan ke dalam labu ukur $10 \mathrm{~mL}$, masing-masing $0,1 \mathrm{~mL} ; 0,2 \mathrm{~mL} ; 0,3 \mathrm{~mL} ; 0,4$ $\mathrm{mL}$ dan $0,5 \mathrm{~mL}$. Selanjutnya, ditambahkan $1,5 \mathrm{~mL}$ larutan 1,10-fenantrolin $1000 \mathrm{ppm} ; 1 \mathrm{~mL}$ buffer asetat $\mathrm{pH} 3,5$ dan $5 \mathrm{~mL}$ aseton. Campuran tersebut diencerkan menggunakan aqua DM hingga tanda batas, lalu dikocok sampai homogen, dan didiamkan selama 5 menit. Absorbansi diukur pada panjang gelombang maksimum yang telah diperoleh. Masing-masing prosedur diulang sebanyak dua kali. Data yang diperoleh dibuat kurva kalibrasi antara konsentrasi terhadap absorbansi, kemudian ditentukan kemiringannya (slope).

\section{H. Pembuatan Kurva Kalibrasi Kadmium(II)} Fenantrolin

Larutan Kadmium (II) 100 ppm dimasukkan ke dalam labu ukur $10 \mathrm{~mL}$, masing-masing $0,1 \mathrm{~mL} ; 0,2 \mathrm{~mL} ; 0,3$ $\mathrm{mL} ; 0,4 \mathrm{~mL}$ dan $0,5 \mathrm{~mL}$. Selanjutnya, ditambahkan 1,5 $\mathrm{mL}$ larutan 1,10-fenantrolin $1000 \mathrm{ppm} ; 1 \mathrm{~mL}$ buffer asetat $\mathrm{pH} 3,5$ dan $5 \mathrm{~mL}$ aseton. Campuran tersebut diencerkan menggunakan aqua DM hingga tanda batas, lalu dikocok sampai homogen, dan didiamkan selama 5 menit. Absorbansi diukur pada panjang gelombang maksimum yang telah diperoleh. Masing-masing prosedur diulang sebanyak dua kali. Data yang diperoleh dibuat kurva kalibrasi antara konsentrasi terhadap absorbansi, kemudian ditentukan kemiringannya (slope).

\section{Analisis Gangguan Kadmium(II) terhadap Besi(III)} Fenantrolin

Analisis gangguan kadmium(II) terhadab Besi(III) Fenantrolin dapat ditentukan dengan cara, diambil 0,5 $\mathrm{mL}$ larutan $\mathrm{Fe}$ (III) 100 ppm, lalu dimasukkan dalam labu ukur $10 \mathrm{~mL}$, kemudian ditambahkan dengan $0,5 \mathrm{~mL}$ kadmium, 1,5 mL larutan 1,10-fenantrolin 1000 ppm; 1 $\mathrm{mL}$ buffer asetat $\mathrm{pH} 3,5$ dan $5 \mathrm{~mL}$ aseton. Campuran tersebut ditambahkan aqua DM hingga volume $10 \mathrm{~mL}$, dikocok hingga homogen dan didiamkan selama 5 menit. Selanjutnya diukur absorbansinya pada panjang gelombang 300 - $750 \mathrm{~nm}$ dengan rentang $1 \mathrm{~nm}$.

\section{J. Pengaruh Cd(II) pada Kondisi pH 3,5}

Larutan $\mathrm{Fe}(\mathrm{III}) 100$ ppm masing-masing dipipet sebanyak 0,5 mL kedalam masing-masing 6 labu ukur 10 $\mathrm{mL}$, kemudian larutan kadmium(II) $100 \mathrm{ppm}$ ditambahkan sebanyak $0,01 \mathrm{~mL} ; 0,02 \mathrm{~mL} ; 0,03 \mathrm{~mL} ; 0,04$ $\mathrm{mL} ; 0,05 \mathrm{~mL} ; 0,06 \mathrm{~mL} ; 0,07 \mathrm{~mL} ; 0,08 \mathrm{~mL} ; 0,09 \mathrm{~mL}$ serta $0,1 \mathrm{~mL}$ pada masing-masing tabung, da nada 1 tabung yang tidak ditambahkan dengan kadmium(II) 100 ppm. Selanjutnya, ditambahkan $1,5 \mathrm{~mL}$ larutan 1,10 fenantrolin $1000 \mathrm{ppm} ; 1 \mathrm{~mL}$ buffer asetat $\mathrm{pH} 3,5$ dan 5 $\mathrm{mL}$ aseton. Campuran tersebut diencerkan dengan aqua DM hingga $10 \mathrm{~mL}$, kemudian dikocok sampai homogen dan didiamkan selama 5 menit. Absorbansinya diukur pada panjang gelombang maksimum. Masing-masing prosedur diulangi sebanyak tiga kali.

\section{K. Pembuatan Blanko}

Blanko dibuat dengan mencampurkan $1,5 \mathrm{~mL}$ larutan 1,10-fenantrolin $1000 \mathrm{ppm} ; 1 \mathrm{~mL}$ buffer asetat $\mathrm{pH} \mathrm{3,5}$ dan $5 \mathrm{~mL}$ aseton, kemudian campuran tersebut diencerkan dengan aqua DM hingga $10 \mathrm{~mL}$ dan dikocok sampai homogen.

\section{HASIL DAN PEMBAHASAN}

\section{A. Penentuan Panjang Gelombang Maksimum Kompleks Fe(III) fenantrolin}

Panjang gelombang maksimum kompleks Besi(III) Fenantrolin dapat ditentukan dengan alat spektrofotometer UV-Vis. Panjang gelombang maksimum merupakan, panjang gelombang pada absorbansi tertinggi yang didapat dari hasil analisis menggunakan spektrofotemeter UV-Vis. Absorbansi harus berada pada rentang $0,2-0,8$ [7].

Senyawa orto fenantrolin dengan rumus molekul $\mathrm{C}_{12} \mathrm{H}_{8} \mathrm{~N}_{2}$ dapat bereaksi dengan beberapa jenis logam. Besi (ferum) merupakan salah satu logam yang dapat 
direaksikan dengan orto fenantrolin membentuk kompleks besi(III) fenantrolin [8]. Yang mana dapat ditentukan secara spektrofotometer UV-Vis melalui reaksi sebagai berikut :

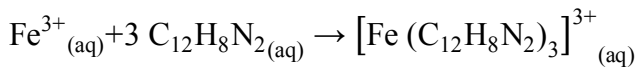

Pengompleks orto fenantrolin, aseton dan larutan buffer asetat $\mathrm{pH}$ 3,5 ditambahkan pada larutan Besi(III). Digunakan Buffer asetat dengan $\mathrm{pH}$ 3,5 yang merupakan $\mathrm{pH}$ optimum untuk pembentukan senyawa kompleks. Aseton ditambahkan untuk memperbesar kelarutan senyawa kompleks[9].

Dilakukan pendiaman larutan kompleks selama 5 menit untuk pelarutan secara merata. Perlakuan yang diberikan pada larutan kompleks tidak boleh lebih dari 20 menit, karena kestabilan ion $\mathrm{Fe}^{3+}$ hanya pada kurun waktu 20 menit saja [5].

Spektrofotometer UV-Vis dengan panjang gelombang 300-750 nm digunakan untuk mengukur panjang gelombang maksimum dari larutan kompleks. Digunakan blanko yang berupa semua bahan yang dipakai untuk pembuatan larutan kompleks, kecuali Fe(III). Selanjutnya, dibuat kurva panjang gelombang maksimum yang ditunjukkan pada Gambar 1.

\section{Panjang Gelombang Maksimum Fe(III)}

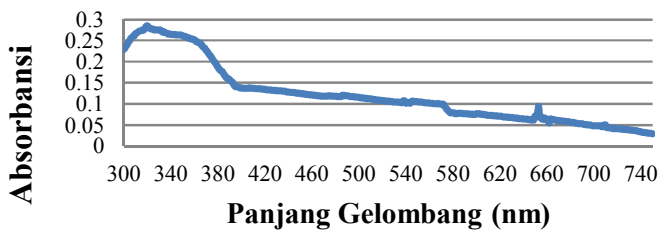

Gambar 1. Grafik Panjang Gelombang maksimum Fe(III) Fenantrolin interval $40 \mathrm{~nm}$

Gambar 1 dilihat bahwa, absorbansi maksimal berada pada panjang gelombang 315-325 nm dengan interval 40 nm. Untuk mengetahui panjang gelombang pada absorbansi maksimum, maka interval diubah menjadi 1 nm. Dan didapatkan kurva seperti pada Gambar 2.

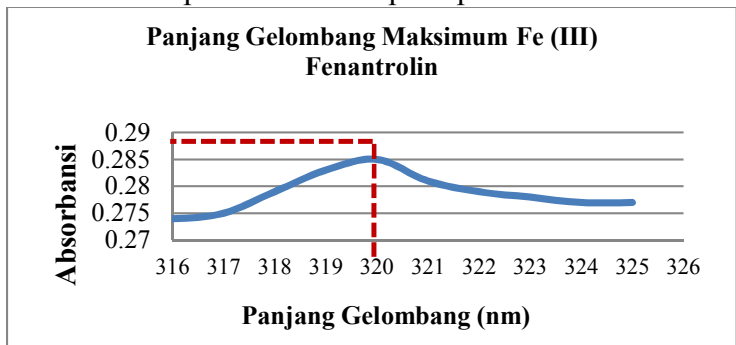

Gambar 2. Grafik Panjang Gelombang Maksimum Fe(III) Fenantrolin interval $1 \mathrm{~nm}$

Gambar 2 dapat dilihat bahwa, panjang gelombang maksimum kompleks Besi(III) Fenantrolin adalah 320 nm dengan absorbansi tertinggi yaitu 0,285.

Besi merupakan logam transisi dengan konfigurasi electron dan hibridisasi sebagai berikut :

Konfigurasi :

${ }_{26} \mathrm{Fe}: 1 \mathrm{~s}^{2} 2 \mathrm{~s}^{2} 2 \mathrm{p}^{6} 3 \mathrm{~s}^{2} 3 \mathrm{p}^{6} 4 \mathrm{~s}^{2} 3 \mathrm{~d}^{6}$

${ }_{26} \mathrm{Fe}: 1 \mathrm{~s}^{2} 2 \mathrm{~s}^{2} 2 \mathrm{p}^{6} 3 \mathrm{~s}^{2} 3 \mathrm{p}^{6} 3 \mathrm{~d}^{6} 4 \mathrm{~s}^{2}$

${ }_{26} \mathrm{Fe}^{3+}: 1 \mathrm{~s}^{2} 2 \mathrm{~s}^{2} 2 \mathrm{p}^{6} 3 \mathrm{~s}^{2} 3 \mathrm{p}^{6} 3 \mathrm{~d}^{5} 4 \mathrm{~s}^{0}$

Hibridisasi :

Besi(III) Fenantrolin

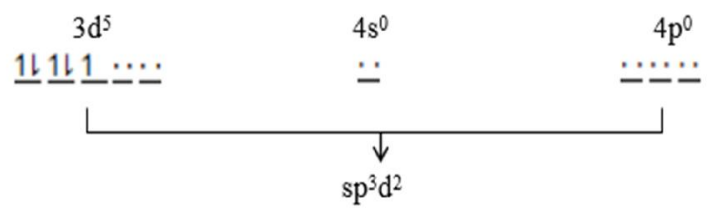

Besi dikomplekskan dengan fenantrolin membentuk kompleks Besi(III) Fenantrolin dengan hibridisasi $\mathrm{sp}^{3} \mathrm{~d}^{2}$ yang memiliki bentuk geometri oktahedral seperti pada Gambar 3.

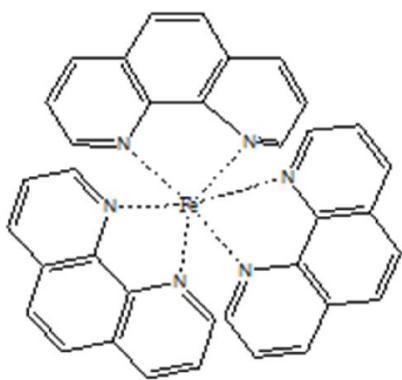

Gambar 3. Struktur Oktahedral Fe(III) Fenantrolin

\section{B. Penenentuan Panjang Gelombang Maksimum Cd (II) fenantrolin}

Panjang gelombang maksimum kompleks Kadmium(II) Fenantrolin juga dapat ditentukan dengan alat spektrofotometer UV-Vis. Absorbansi yang didapat, juga harus berada pada rentang 0,2-0,8 seperti Besi(III) Fenantrolin. Cd (Kadmium) merupakan salah satu logam yang dapat direaksikan dengan orto fenantrolin membentuk kompleks Kadmium(II) fenantrolin [8]. Yang mana dapat ditentukan secara spektrofotometer $\mathrm{UV}-\mathrm{Vis}$ melalui reaksi sebagai berikut :

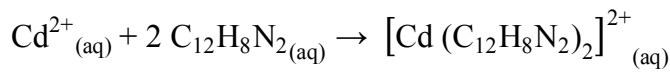

Diberikan perlakuan yang sama dengan penentuan panjang gelombang maksimum Besi(III) Fenantrolin. Spektrofotometer UV-Vis dengan panjang gelombang 300-750 nm, juga digunakan untuk mengukur panjang gelombang maksimum dari larutan kompleks. Digunakan blanko yang berupa semua bahan yang dipakai untuk pembuatan larutan kompleks, kecuali $\mathrm{Cd}(\mathrm{II})$ Selanjutnya, dibuat kurva panjang gelombang maksimum yang ditunjukkan pada Gambar 4.

\section{Panjang Gelombang Maksimum Kadmium (II)}

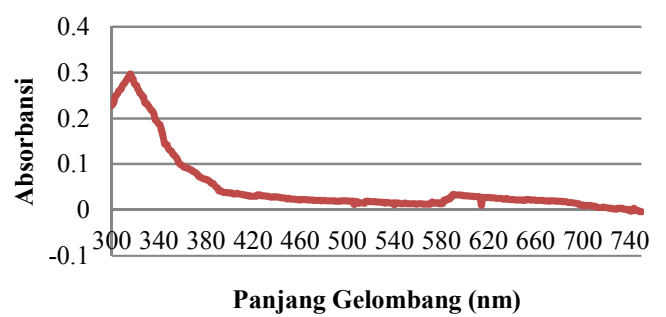

Gambar 4. Grafik Panjang Gelombang Maksimum Cd(II) Fenantrolin interval $40 \mathrm{~nm}$

Gambar 4. dilihat bahwa, absorbansi maksimal berada pada panjang gelombang 310-320 nm dengan interval 40 nm. Untuk mengetahui panjang gelombang pada absorbansi maksimum, maka interval diubah menjadi 1 nm. Didapatkan kurva seperti pada Gambar 5. 


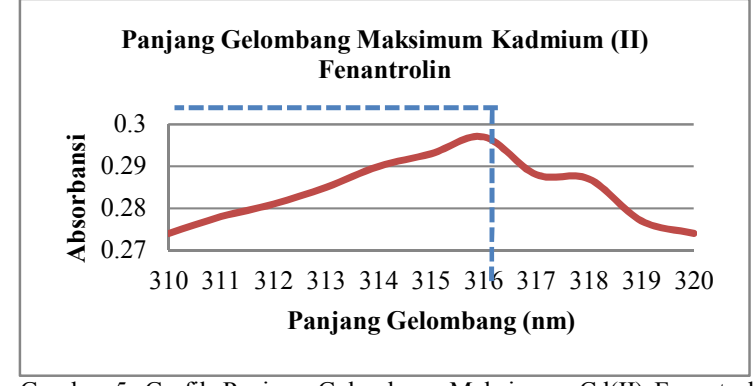

Gambar 5. Grafik Panjang Gelombang Maksimum Cd(II) Fenantrolin Interval $1 \mathrm{~nm}$

Gambar 5 dapat dilihat bahwa, panjang gelombang maksimum kompleks Kadmium(II) Fenantrolin adalah $316 \mathrm{~nm}$ dengan absorbansi tertinggi yaitu 0,297.

Kadmium merupakan logam dengan konfigurasi electron dan hibridisasi sebagai berikut :

Konfigurasi :

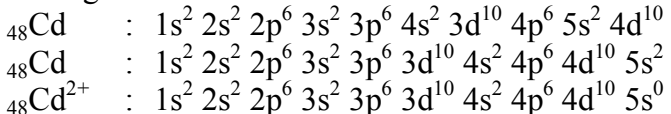

Hibridisasi :

Kadmium(II) Fenantrolin

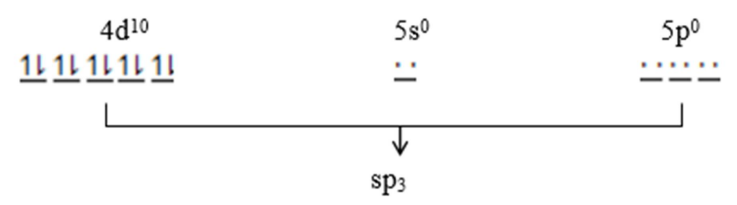

Kadmium dikomplekskan dengan fenantrolin membentuk Kadmium(II) Fenantrolin dengan hibridisasi $\mathrm{sp}^{3}$ yang memiliki bentuk geometri tetrahedral seperti pada Gambar 6.

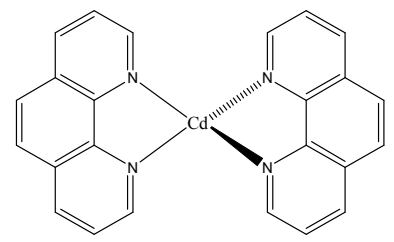

Gambar 6. Struktur Tetrahedral Cd(II) Fenantrolin

\section{Pembuatan Kurva Kalibrasi Besi(III) Fenantrolin}

Kurva kalibrasi dibuat dengan mengukur absorbansi kompleks Besi(III) Fenantrolin pada panjang gelombang maksimum (320 nm). Digunakan variasi konsentrasi $\mathrm{Fe}^{3+}$ 1,2,3,4 dan 5 ppm.Data absorbansi yang didapat pada masing-masing konsentrasi Ferum adalah seperti pada Tabel 1.

Tabel 1.

Hasil absorbansi Besi(III) Fenantrolin pada panjang gelombang maksimum

\begin{tabular}{cc}
\hline \hline Konsentrasi (ppm) & Absorbansi \\
\hline 0 & 0 \\
1 & 0.108 \\
2 & 0.197 \\
3 & 0.296 \\
4 & 0.409 \\
5 & 0.511 \\
\hline \hline
\end{tabular}

Dibuat grafik kurva standart dari data absorbansi pada masing - masing konsentrasi yang didapat. Yang mana sumbu $\mathrm{x}$ adalah konsentrasi dan sumbu $\mathrm{y}$ adalah absorbansi. Grafik kurva standart dapat dilihat pada Gambar 7.

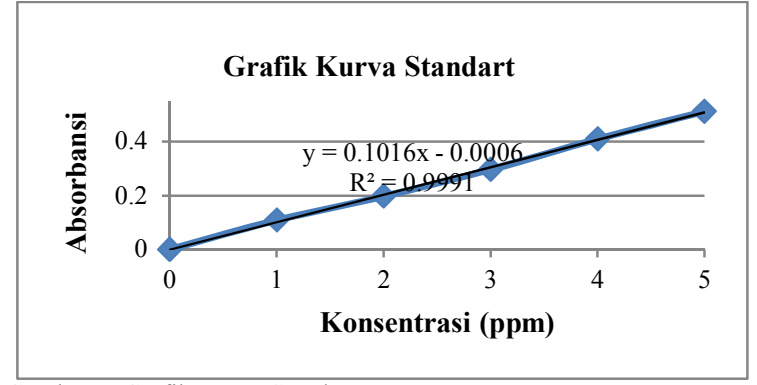

Gambar 7. Grafik Kurva Standart

Kurva standart dibuat sebagai standart dalam penentuan analisis gangguan Kadmium(II) terhada Besi(III). Dari kurva standart, didapat hasil regresi sebesar $\mathrm{y}=0,1016 \mathrm{x}-0,0006$ dengan nilai regresi $r^{2}=0,9991$. Nilai regresi ini menunjukkan adanya korelasi yang erat antara absorbansi dengan konsentrasi. Karena memiliki nilai regresi $0,9940<\mathrm{r}^{2}<1$ [7].

D. Pembuatan Kurva Kalibrasi Kadmium(II)

Kurva kalibrasi dibuat dengan mengukur absorbansi kompleks Kadmium(II) Fenantrolin pada panjang gelombang maksimum (316 nm). Digunakan variasi konsentrasi $\mathrm{Cd}^{2+} 1,2,3,4$ dan 5 ppm. Adapun data absorbansi yang didapat pada masing - masing konsentrasi Kadmium adalah seperti pada Tabel 2.

$$
\text { Tabel } 2 .
$$

Hasil absorbansi Besi(III) Fenantrolin pada panjang gelombang maksimum

\begin{tabular}{cc}
\hline \hline Konsentrasi (ppm) & Absorbansi \\
\hline 0 & 0 \\
1 & 0.144 \\
2 & 0.262 \\
3 & 0.376 \\
4 & 0.487 \\
5 & 0.598 \\
\hline \hline
\end{tabular}

Dibuat grafik kurva standart dari data absorbansi pada masing - masing konsentrasi yang didapat. Yang mana sumbu $\mathrm{x}$ adalah konsentrasi dan sumbu $\mathrm{y}$ adalah absorbansi. Grafik kurva standart dapat dilihat pada Gambar 8 .

\section{Grafik Kurva Standart Cd (II) Fenantrolin}

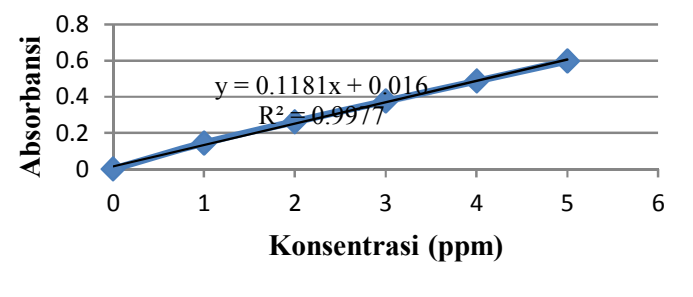

Gambar 8. Grafik Kurva Standart Cd (II) Fenantrolin

Dari kurva standart, didapat hasil regresi sebesar $\mathrm{y}=$ $0,1181 x+0,016$ dengan nilai regresi $r^{2}=0,9977$. Nilai regresi ini menunjukkan adanya korelasi yang erat antara absorbansi dengan konsentrasi.

\section{E. Analisis Gangguan Kadmium(II) terhadap Besi(III) Fenantrolin}

Berdasarkan data yang telah didapat pada sub bab A dan $\mathrm{B}$, maka dapat dilakukan analisis mengenai ada dan tidaknya gangguan yang diberikan oleh ion $\mathrm{Cd}^{2+}$ kepada $\mathrm{Fe}^{3+}$. Hal ini dapat dilakukan dengan menggabungkan 
grafik pada Gambar 1 dan 4, seperti pada Gambar 9 berikut.

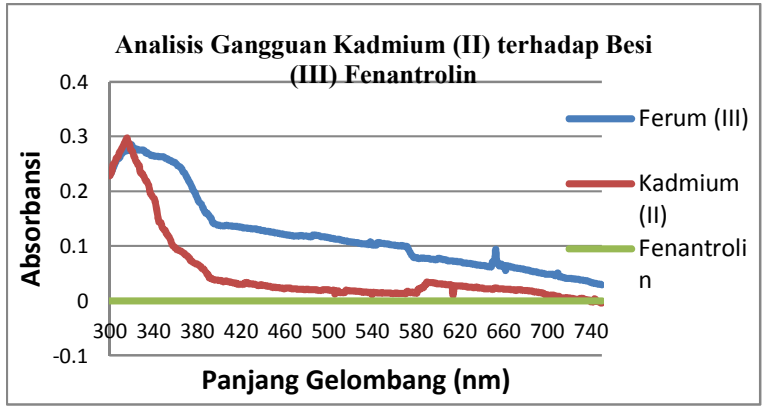

Gambar 9. Grafik Analisis Gangguan Kadmium(II) terhadap Besi(III) Fenantrolin

Grafik diatas merupakan grafik penggabungan dari grafik panjang gelombang maksimum besi(III) Fenantrolin dengan kadmium(II) Fenantrolin yang mana masing - masing memiliki konsentrasi 5 ppm, dengan penambahan fenantrolin masing - masing $150 \mathrm{ppm}$ sebagai pengompleks.

Dapat dilihat adanya perpotongan garis antara Besi dan Kadmium. Menandakan adanya gangguan yang diberikan oleh kadmium kepada besi. Kemungkinan adanya gangguan pada konsentrasi kecil, karena grafik saling berpotongan (Wang, 2015). Untuk gambar lebih jelasnya lagi dapat dilihat pada Gambar 10 dengan interval $1 \mathrm{~nm}$. Yang mana, pada grafik menunjukkan ada nya perpotongan pada panjang gelombang maksimum, yaitu sekitar 320 .

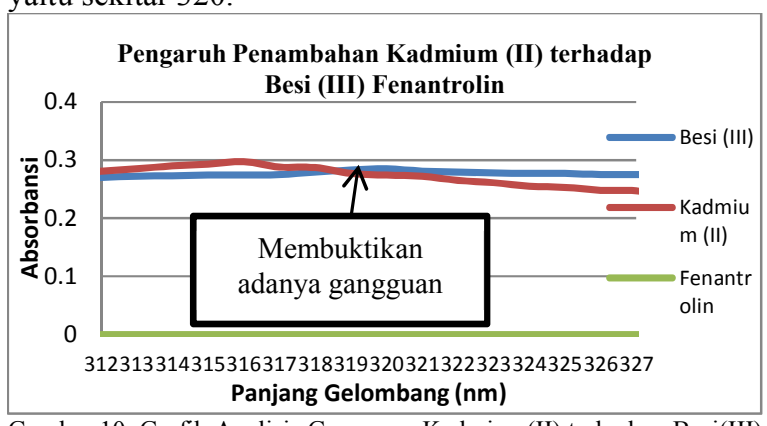

Gambar 10. Grafik Analisis Gangguan Kadmium(II) terhadap Besi(III) Fenantrolin Interval $1 \mathrm{~nm}$

Setelah dilakukan penggabungan data dan terdapat indikasi gangguan yang diberikan oleh kadmium(II) terhadap besi(III) fenantrolin, dilakukan uji dengan penambahan kadmium(II) 5 ppm ke dalam kompleks besi(III) fenantrolin. Kemudian di dapat data absorbansi dan panjang gelombang seperti pada Gambar 11.

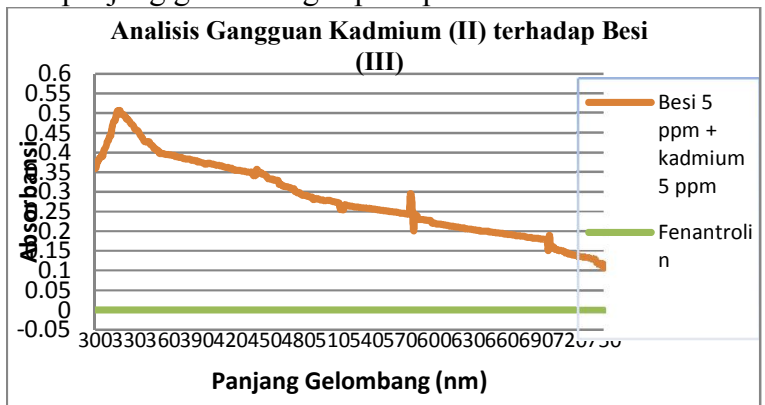

Gambar 11. Grafik Gangguan Kadmium(II) terhadap Besi(III) Fenantrolin

Grafik diatas merupakan grafik setelah dilakukan penambahan Kadmium(II) 5 ppm ke dalam Besi(III) 5 ppm yang telah terkomplekskan dengan fenantrolin 150 ppm. Pada panjang gelombang maksimumnya, mengalami kenaikan puncak dari grafik sebelum pencampuran. Ketika sebelum dicampurkan absorbansi sekitar 0,285 - 0,297, ketika dilakukan pengukuran setelah menambahkan kadmium pada besi(III), absorbansi meningkat menjadi 0,507.

\section{F. Pengaruh Cd(II) pada Kondisi pH 3,5}

Dilakukan uji gangguan dengan menambahkan Kadmium(II) kedalam larutan kompleks Besi(III) Fenantrolin dengan variasi 0,$1 ; 0,2 ; 0,3 ; 0,4 ; 0,5 ; 0,6$; 0,$7 ; 0,8 ; 0,9$ dan $1 \mathrm{ppm}$, serta ada 1 tabung yamg tidak ditambahkan. Ditambahkan Besi(III) : 1,10-fenantrolin sebesar 1:30. Besi(III) Fenantrolin yang digunakan yaitu 5 ppm, dan 1,10-fenantrolin 150 ppm. Ditambahkan buffer asetat $\mathrm{pH}$ 3,5 dan aseton $5 \mathrm{~mL}$, lalu di lakukan analisis UV-Vis pada panjang gelombang maksimum $320 \mathrm{~nm}$. Dari hasil analisis spektrofotometer UV-Vis, di dapatkan data pada Tabel 3.

$$
\text { Tabel } 3 .
$$

Data Absorbansi dan Recovery Setelah Penambahan Kadmium(II)

\begin{tabular}{cccc}
\hline \hline $\begin{array}{c}\text { Konsentrasi } \\
\text { Kadmium (ppm) }\end{array}$ & Absorbansi & $\begin{array}{c}\text { Konsentrasi } \\
\text { Ferum (ppm) }\end{array}$ & \% Recovery \\
\hline 0 & 0.498 & 4.907 & 98.149 \\
0.1 & 0.507 & 4.996 & 99.921 \\
0.2 & 0.529 & 5.212 & 104.251 \\
0.3 & 0.533 & 5.251 & 105.039 \\
0.4 & 0.574 & 5.655 & 113.110 \\
0.5 & 0.598 & 5.891 & 117.834 \\
0.6 & 0.617 & 6.078 & 121.574 \\
0.7 & 0.629 & 6.196 & 123.937 \\
0.8 & 0.635 & 6.255 & 125.118 \\
0.9 & 0.661 & 6.511 & 130.236 \\
1 & 0.688 & 6.777 & 135.551 \\
\hline \hline
\end{tabular}

Kadmium dikatakan mengganggu Besi, ketika \% recovery berada diluar interval 80-120\%. Dapat dilihat pada tabel 3, bahwa pada penambahan Kadmium 0,6 ppm dengan persen recovery $121,574 \%$, berada diluar interval tersebut. Hal ini dapat menunjukkan bahwa Kadmium(II) mulai mengganggu Besi(III) pada konsentrasi 0,6 ppm. Hasil ini dapat diperjelas dengan grafik pada Gambar 12.

Besi yang ditambahkan sebesar 5 ppm dengan pengompleks 1,10-fenantrolin sebesa $150 \mathrm{ppm}$, yaitu 1:30. Maka, fenantrolin yang diberikan berlebih, baik pada besi maupun kadmium, yang mana akan membentuk kompleks besi(III) fenantrolin dan kadmium(II) Fenantrolin. Ketika ditambahkan kadmium yang merupakan ion pengganggu pada penelitian kali ini, maka kadmium akan bereaksi dengan 1,10-fenantrolin, karena kadmium juga dapat membentuk kompleks dengan 1,10-fenantrolin menjadi Kadmium(II) fenantrolin yang lebih stabil dibandingkan dengan kompleks besi(III) fenantrolin.

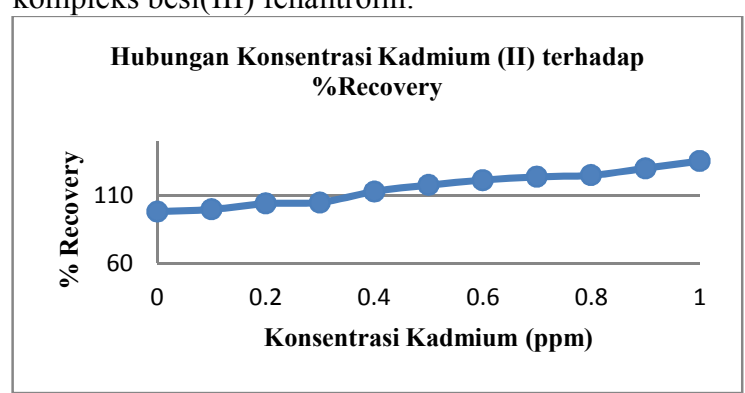

Gambar 12. Hubungan Konsentrasi Kadmium(II) terhadap \% Recovery 


\section{KESIMPULAN}

Berdasarkan penelitian yang telah dilakukan, maka dapat disimpulkan bahwa analisis Besi(III) dengan pengompleks orto fenantrolin menjadi Besi(III) Fenantrolin pada $\mathrm{pH}$ 3,5 dapat diganggu oleh Kadmium(II) dengan menurunkan nilai absorban. Kadmium(II) mulai mengganggu kestabilan kompleks Besi(III) Fenantrolin pada konsentrasi 0,6 ppm pada konsentrasi Besi(III) 5 ppm dengan nilai recovery sebesar $121,574 \%$.

\section{DAFTAR PUSTAKA}

[1] Effendy. 2007. Kimia Koordinasi First Edition. Malang : Bayumedia. Eramedia team. 2008. Kamus Pintar Kimia. Jakarta : Era Media Publisher

[2] Dewi, Ricma. 2014. Penentuan Kondisi Optimum pada Pembentukan Kompleks Fe(III)-Fenantrolin dengan Spektrofotometri UV-Vis. Skripsi. Surabaya : Institut Teknologi Sepuluh Nopember

[3] Lide, D. R., dkk. 2000. Magnetic susceptibility of the elements and inorganic compounds. Prancis : CRC Press

[4] Cotton, Albert F dan Wilkinson, Geoffrey. 1989. Kimia Anorganik Dasar. Jakarta : UI Press

[5] Charlena. 2004. Pencemaran Logam BeratTimbal dan Kadmium pada Sayur. Bogor : PSL 702 IPB

[6] Hendayana, S., Kadarohman, A., Sumarna, A., dan Supriatna, A., 1994. Kimia Analitik Instrumen, edisi ke-1. IKIP Press. Semarang

[7] Haryadi W. 1992. Ilmu Kimia Analitik Dasar. Jakarta : Gramedia Pustaka Utama

[8] Day, Underwood. 1989. Analisis Kimia Kuantitatif. Jakarta : Erlangga 